\title{
Survival Patterns of Major Perennials in Salt Desert Shrub Communities of Southwestern
}

Utah

NEIL E. WEST

\begin{abstract}
Chart quadrat records periodically taken at the Desert Experimental Range in southwestern Utah over 34 years were examined for evidence of establishment and survival of eight major perennial plant species. A set of seedlings that became established in 1935-37 were followed until 1968-70. Relatively few individuals have died since the second year after establishment. There were few significant differences between the survival of plants in the grazed versus ungrazed plots.
\end{abstract}

West et al. (1979) recently reviewed the relevant literature and noted the dearth of demographic data dealing with perennial plants in arid and semiarid environments. Further comparative studies describing survivorship curves and discussion of how mortality and longevity vary with environmental perturbations seem appropriate. Unfortunately, there exist few sources of longterm data complete enough to perform analyses like those West et al. (1979) did on 21 + years of pantograph records taken on the U.S. Sheep Station in southeastern Idaho. There exist, however, at other research stations periodic pantograph or chart quadrat records and stand maps that could be of some use in exploring these issues. The following is an attempt to use such data from the Desert Experiment Range (DER) in southwestern Utah.

\section{Study Area}

The DER is representative of the salt-desert shrub type (Branson et al. 1967). The station was established in 1933 for the study of range management problems which developed from livestock grazing in the eastern Great Basin. Average annual precipitation recorded at the DER is around $15 \mathrm{~cm}$, but varies greatly according to year and season. There is a slight peak in precipitation in the July-August period. Temperatures can range from $-34^{\circ} \mathrm{C}$ in the winter to $40^{\circ} \mathrm{C}$ in the summer. Other environmental data plus intensities, timing, and effects of sheep grazing are summarized in Hutchings and Stewart (1947), Hutchings (1966), Holmgren and Hutchings (1972), and Holmgren

\footnotetext{
Author is professor, Department of Range Science, Utah State University, Logan 84322 .

The data discussed in this paper were collected by employees of the Intermountain Forest and Range Experiment Station, Forest Service, U.S. Department of Agriculture. The author gratefully acknowledges permission of the Intermountain Station to utilize these data. Ralph Holmgren, of that agency, helped choose the situations with the best data sets and offered critiques of manuscripts. Ms. Carol Gunn reduced the raw data to analyzable form. Mr. Robert Bayn and Mr. Richard Young conducted the statistical analyses. Dr. Brien Norton kindly offered access to relevant manuscripts in preparation. The interpretation of results are solely the authors responsibility.

The study was undertaken with financial support from the National Science Foundation, Grants No. GB-15886 and DEB-74-02671-AU7 to the U.S./I.B.P. Desert Biome Program.

Manuscript received July 3, 1978.
}

(1975). Briefly, within each of sixteen 320-acre paddocks, consistent levels of grazing intensity and timing of sheep grazing have been applied for the past $38+$ years. There have been three different periods within the winter grazing season represented among the 16 paddocks. Four pairs of $5 \times 20$-foot permanent plots were chosen within each paddock for initial topographic and vegetational homogeneity in 1934. Two quadrats were established inside and matched to two quadrats outside each of the two grazing exclosures in each paddock. Thus, four grazed and four ungrazed plots were established and studied in each paddock.

\section{Methods}

Charts of vegetation from four matching pairs of grazed and ungrazed plots in each of six paddocks where the records were most complete were chosen for detailed study. All these plots had been mapped during the summer season of 1935, 1936, 1937, and 1958. They were all mapped once more in early 1968, 1969, or 1970. Perennial plant position and cover were sketched to scale on $8 \times$ 10-inch graph paper.

Investigation of the charts showed that individuals could be identified and noted when they first appeared during the 1935-37 period and when they subsequently disappeared. Because of the omission of many intervening years of data, the cohort life table approach could not be used to describe the demography of these plant populations, nor was it possible to destructively sample to determine ages via stem growth rings for the static life table approach. The success of such a procedure would have been questionable anyway. since there are numerous problems with age dating of the shrubs involved (Ferguson 1962). Inability to age forbs and grasses also precluded this approach. Because of highly questionable size-age relationships in similar species (West et al. 1979), we chose not to extrapolate from size data. We were therefore prevented from drawing conventional survivorship curves.

Woolhouse (1972) favors on theoretical grounds sharp initial declines in survivorship. In deserts this is likely, because of the essentially random nature of environmental disturbances (Noy-Meir 1973). This has been verified for seedlings of two of the species involved (Gasto 1969; Gasto and West 1970). Log-log regressions have been found to best fit the overall survivorship curves of other cold-winter desert plant species (West et al. 1979). These findings caused mistrust of the negative exponential model and the survivorship ratio techniques used by Treshow and Harper (1974) and others, based on assumptions of constant loss of individuals over time. The alternatives of tabular and graphical treatment of available data were the best remaining possibilities.

Seedlings which appeared in a given year (cohort) were tabulated separately for all grazed and ungrazed plots. A three-way factorial 
analysis of variance was used to evaluate plant survival; main effects included species, grazing, and time. Data from all grazed plots were combined within paddocks because of the small number of seedlings. This condensation is further warranted because of the small differences in vegetation and its changes between the plots with different intensities of use (Norton 1978). Survivorship of the cohorts over time was graphed. The differences in the shape of the resultant curves for grazed and ungrazed plots (one for each cohort of each species) were tested for significant differences by the KolmonogorovSmirnov test (Tate and Clelland 1957; West et al. 1979).

\section{Results and Discussion}

A summarization of the seedlings established in 1935 and 1936 and their consequent survival is presented in Tables 1 and
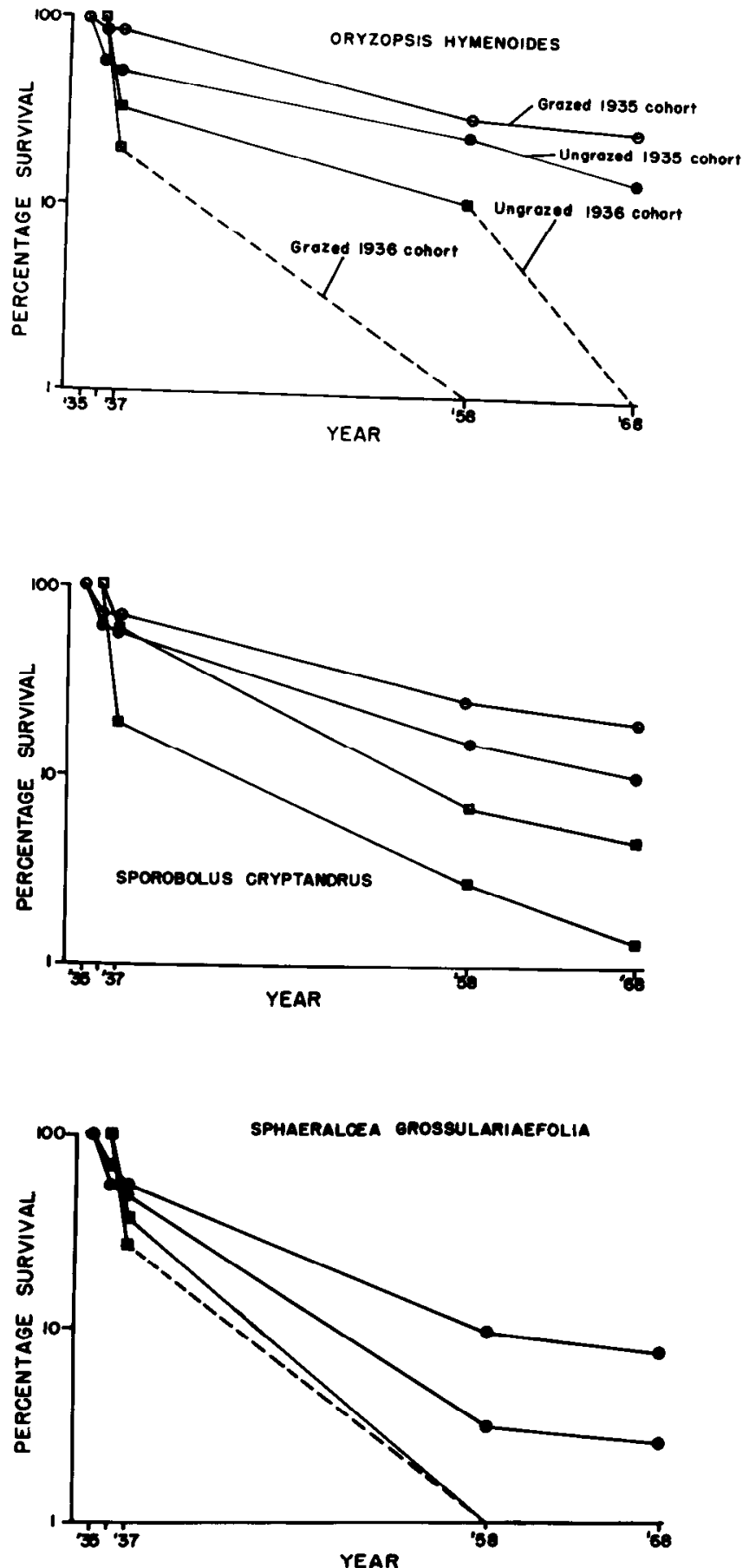

2. Data from the 1937 cohort are omitted here due to the lack of any seedling establishment in many plots that year. The previous spring had been drier than average with apparently less seed production. The spring of 1937 was also dry and shrub seedlings, in particular, were rare.

Tabular values show that the highest densities of establishment and survival were usually on the ungrazed plots for all perennials collectively and most species. Exceptions were establishment of Ceratoides in 1935 and Atriplex, Ceratoides, Sphaeralcea and the total perennial seedlings in 1936. Densities of survivors appeared to become nearly equal through time.

Analysis of variance of the tabular data showed a significant $(P \leq 0.01)$ effect due to time but no statistically significant $(P \leq 0.1)$ differences between grazed or ungrazed populations
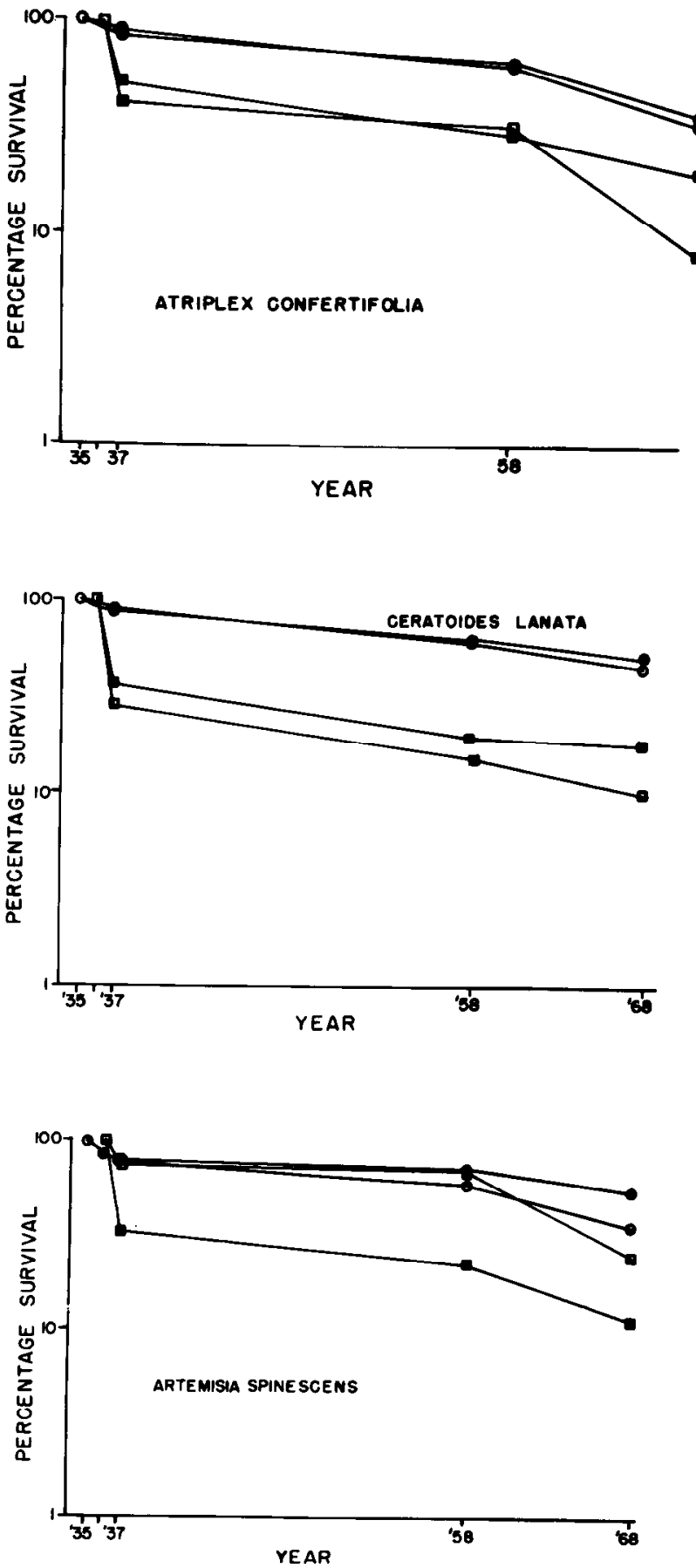

Fig. 1. Percentage survivorship of 1935 and 1936 cohorts of major species at the Desert Experimental Range. Dashed lines indicate interpolation to zero survival. 
Table 1. Establishment and survival through time of the 1935 cohort. Treatments: $\mathbf{G}=$ grazed plots, $U=$ ungrazed plots.

\begin{tabular}{|c|c|c|c|c|c|c|}
\hline Species & Treatment & 1935 & 1936 & 1937 & 1958 & 1968 \\
\hline \multicolumn{7}{|l|}{ Shrubs and half-shrubs } \\
\hline Atriplex confertifolia & G & 256 & 229 & 218 & 171 & 97 \\
\hline (Torr. \& Frem.) S. Wats & $\mathbf{U}$ & 263 & 241 & 233 & 166 & 95 \\
\hline Artemisia spinescens & G & 66 & 58 & 53 & 40 & 24 \\
\hline D.C. Eaton & $\mathrm{U}$ & 70 & 61 & 58 & 52 & 41 \\
\hline Ceratoides lanata (Pursh) & $\mathbf{G}$ & 511 & 472 & 472 & 313 & 226 \\
\hline J.T. Howell & $\mathrm{U}$ & 480 & 446 & 431 & 320 & 240 \\
\hline \multicolumn{7}{|l|}{ Grasses } \\
\hline Oryzopsish & G & 25 & 22 & 22 & 8 & \\
\hline ult.) Ricker & $\mathrm{U}$ & 40 & 24 & 21 & 10 & 6 \\
\hline Sporobolus cryptandrus & G & 155 & 112 & 101 & 39 & 33 \\
\hline (Torr.) A. Gray & $\mathrm{U}$ & 290 & 185 & 165 & 45 & 31 \\
\hline \multicolumn{7}{|l|}{ Forbs } \\
\hline Sphaeralcea grossulari- & G & 51 & 36 & 28 & 5 & \\
\hline aefolia (Hook. \& Arn.) & $\mathrm{U}$ & 189 & 111 & 91 & 6 & $\varepsilon$ \\
\hline \multicolumn{7}{|l|}{ Rydb. } \\
\hline Total number of seedlings & G & 1064 & 950 & 894 & 576 & 391 \\
\hline of perennials & $\mathbf{U}$ & 1322 & 1068 & 999 & 599 & 418 \\
\hline
\end{tabular}

for most species or all perennials combined.

All are too long-lived to determine their maximum logevity via analysis of these records; that is, at least one of their individuals survived the 34 years of record. The records were not taken frequently enough to allow calculation of average longevities.

Percentage survivorship curves for the 1935 and 1936 cohorts are presented in Figure 1. These curves show that ungrazed plots, except for the 1935 cohort of Artemisia, both cohorts of Ceratoides, and 1936 cohort of Atriplex and Oryzopsis showed lower percentage survival at the end of the study than grazed plots. In other words, plants showed better survival on grazed plots more often than those on ungrazed plots. Only Ceratoides showed better survival for both cohorts when livestock grazing was excluded. The other shrubs (Atriplex and Artemisia) showed mixed results in this respect. The one forb and one grass (Sporobolus) consistently showed a higher percentage survival on the grazed plots. These results are counter-intuitive since Wood (1966) previously showed numerically higher survival of Artemisia on ungrazed plots at DER. He attributed higher mortality on grazed plots to livestock trampling, Perhaps, the grazed plots were more open to seedling establishment. Competition was possibly less in the grazed stands. Menzies (1935), McGuire (1937), Stewart et al. (1940), and Harper (1959) all found generally less total plant cover and density plus a greater proportion of younger plants on grazed plots in the same and similar valleys of southwestern Utah.

The shapes of the survivorship curves were consistently different for the 1935 and 1936 cohorts. The survival of seedlings established in 1936 usually showed a more marked decline by 1937 than those established in 1935. The comparative loss during the first year after appearance was also usually greater for the 1936 cohort. This poorer start was followed by generally steeper rates of mortality as the plants aged. Perhaps the initial development of plant size, especially root structure, was critical to average longevity (Harper 1977).

The results of the Kolmonogorov-Smirnov tests indicated no overall significant differences in the shape of the survivorship curves of grazed and ungrazed populations except for the 1936 cohort of Sporobolus where the differences were significantly different at the $95 \%$, but not the $99 \%$ level.

The shape of most survivorship curves suggested that the
Table 2. Establishment and survival through time of the 1936 cohort. Treatments: $\mathbf{G}=$ grazed plots, $\mathrm{U}=$ ungrazed plots.

\begin{tabular}{lcrrrr}
\hline Species & Treatment & 1936 & 1937 & 1958 & 1968 \\
\hline Shrubs and half-shrubs & & & & & \\
$\quad$ Atriplex confertifolia & $\mathrm{G}$ & 12 & 5 & 4 & 1 \\
Artemisia spinescens & $\mathrm{U}$ & 10 & 5 & 3 & 2 \\
& $\mathrm{G}$ & 4 & 3 & 3 & 1 \\
Ceratoides lanata & $\mathrm{U}$ & 9 & 3 & 2 & 1 \\
& $\mathrm{G}$ & 67 & 20 & 10 & 7 \\
& $\mathrm{U}$ & 41 & 15 & 8 & 7 \\
Grasses & & & & & \\
Oryzopsis hymenoides & $\mathrm{G}$ & 5 & 1 & 0 & 0 \\
& $\mathrm{U}$ & 9 & 3 & 1 & 0 \\
Sporobolus cryptandrus & $\mathrm{G}$ & 42 & 25 & 3 & 2 \\
& $\mathrm{U}$ & 72 & 14 & 2 & 1 \\
Forbs & & & & & \\
Sphaeralcea grossulariae- & $\mathrm{G}$ & 143 & 40 & 0 & 0 \\
& $\mathrm{U}$ & 111 & 40 & 1 & 0 \\
Total & $\mathrm{G}$ & 273 & 94 & 20 & 11 \\
& $\mathrm{U}$ & 252 & 80 & 17 & 11 \\
\hline
\end{tabular}

negative exponential curve (constant mortality) may well best describe survivorship of these plants after they reached about 2-3 years of age until they are 34+ years old. Data are too sparse to adequately test various regression models as West et al. (1979) did for other cold-winter desert plants.

The general lack of difference between the survival of grazed or ungrazed populations may be due to the sparseness and thus high variation in the data, or it could be that all the grazing intensities used are so moderate that the historical recovery of the vegetation has been more a response to climatic variation than the grazing treatment (Norton 1978).

\section{Literature Cited}

Branson, F.A., R.F. Miller, and I.S. McQueen. 1967. Geographic distribution of salt desert shrubs in the United States, J. Range Manage. 20:287-298.

Ferguson, C.W. 1962. Annual ring studies of desert shrubs. Tech. Rep. to Nat. Sci. Found. Grant G-5568. 12 p.

Gasto, J. 1969. Comparative autecological studies of Eurotia lanata and Atriplex confertifolia. PhD Diss., Utah State Univ., Logan, Utah. 293 p.

Gasto, J., and N.E. West. 1970. Population dynamics studies of the causes of range condition and trends. Soc. for Range Manage. (Denver, Colo., Feb. 1969). Abstr. of Pap. 22:77.

Harper, J. 1977. The population biology of plants. Academic Press, N.Y. 892 p.

Harper, K.T. 1959. Vegetational changes in a shadscale-winterfat plant association during twenty-three years of controlled grazing. M.S. Thesis, Brigham Young Univ., Provo, Utah. 68 p.

Holmgren, R.C. 1975. The Desert Experimental Range: description, history, and program. p. 18-22. In: D.H. Hyder (ed.). Arid Shrublands. Soc. for Range Manage., Denver, Colo.

Holmgren, R.C., and S.S. Hutchings. 1972. Salt desert shrub response to grazing use. p 153-164. In: Wildland Shrubs-Their Biology and Utilization. U.S. Dep. Agr. Forest Serv. Gen. Tech. Rep. INT-1.

Hutchings, S.S. 1966. Grazing management of salt desert shrub ranges in the western United States Proc. IX Int. Grassland Cng., p. 1619-1625.

Hutchings, S.S., and G. Stewart. 1947. Inceasing forage yields and sheep production on intermountain winter ranges. U.S. Dep. Agr. Circ. 925.63 p.

McGuire, J.H. 1937. The influence of overgrazing on the density and number of palatable and unpalatable desert forage plants. M.S. Thesis, Brigham Young Univ., Provo, Utah. 43 p.

Menzies, C.W. 1935. Effects of overgrazing on the mortality of desert browse of the Utah West Desert. M.S. Thesis, Brigham Young Univ., Provo, Utah. $38 \mathrm{p}$.

Norton, B.E. 1978. The impact of sheep grazing on long-term successional trends in salt desert shrub vegetation of southwestern Utah. p 610-613. In: D.A. Hyder (ed.) Proc. 1st Int. Rangeland Congress, Denver, Colo. 
Noy-Meir, I. 1973. Desert ecosystems: environment and producers. Ann. Rev Ecol. Syst. 4:24-51.

Stewart, G., W.P. Cottam, and S.S. Hutchings. 1940. Influence of unrestricted grazing on northern salt desert plant associations in western Utah. J. Agr. Res. 60:289-316.

Tate, M.W., and R.C. Clelland. 1957. Nonparametric and Shortcut Statistics in the Social. Biological and Medical Sciences. Interstate Printers and Publishers, Danville, Ill. 148 p.
Treshow, M., and K.T. Harper. 1974. Longevity of perennial forbs an grasses. Oikos 25:93-96.

West, N.E., K.H. Rea, and R.O. Harniss. 1979. Plant demographic studie: in sagebrush-grass communities of southeastern Idaho. Ecology 60: (i) press).

Wood, B.W. 1966. An ecological life history of budsage in western Utah M.S. Thesis, Brigham Young University, Provo, Utah. 85 p.

Woolhouse, H.W. 1972. Aging processes in higher plants. Oxford Univ Press. $15 \mathrm{p}$ 